\title{
Application of Value Stream Mapping in E-Commerce: A Case Study on an Amazon Retailer
}

\author{
Yanfang Qin and Hongrui Liu *(D)
}

Citation: Qin, Y.; Liu, H. Application of Value Stream Mapping in E-Commerce: A Case Study on an Amazon Retailer. Sustainability 2022, 14, 713. https://doi.org/10.3390/ su14020713

Academic Editor: Marc Lim

Received: 29 November 2021

Accepted: 3 January 2022

Published: 10 January 2022

Publisher's Note: MDPI stays neutral with regard to jurisdictional claims in published maps and institutional affiliations.

Copyright: (c) 2022 by the authors. Licensee MDPI, Basel, Switzerland. This article is an open access article distributed under the terms and conditions of the Creative Commons Attribution (CC BY) license (https:// creativecommons.org/licenses/by/ $4.0 /)$.
Department of Industrial and Systems Engineering, San José State University, San José, CA 95192, USA; yanfang.qin@sjsu.edu

* Correspondence: Hongrui.liu@sjsu.edu

\begin{abstract}
In recent years, the e-commerce market has grown significantly, and the online retail market has become very competitive. Online retailers strive to improve their supply chain operations to reduce costs and to improve customer satisfaction. Value stream mapping (VSM), a tool created by the lean production movement to identify and reduce errors, losses, and lead time and to improve value-added activities, has been proven to be effective in many manufacturing processes. In this study, we investigate the application of value stream mapping (VSM) in the supply chain of an e-commerce retailer on Amazon. By visualizing the entire supply chain with VSM, the waste that is produced during the delivery process from the retailer to the customer was identified. The five whys method was then applied to find the root cause of the waste. Furthermore, a scoring method was developed to evaluate and compare two different supply chain logistic models to identify a strategy for improvement. This study provides a systematic methodology to understand, evaluate, and improve the entire e-commerce supply chain process utilizing VSM. It was demonstrated that the methodology could improve supply chain management efficiency, customer satisfaction, and cost reduction.
\end{abstract}

Keywords: e-commerce supply chain; value stream mapping; customer satisfaction; cost reduction

\section{Introduction}

E-commerce has been the fastest-growing channel in the retail industry over the last decade, and online buying and selling have become increasingly prevalent $[1,2]$. The coronavirus pandemic 2019 (COVID-19) has changed people's life profoundly, and ecommerce has played an even more important role in maintaining the economic health of society [3]. Euromonitor estimates that $17 \%$ of goods will be bought online in 2021 , nearly doubling from 2016. In 2020, the amount of goods bought online globally grew by $24 \%$, reaching a total of USD 4.2 trillion worldwide, while stored-based sales declined by $7 \%$ [4]. With e-commerce, not only can buyers enjoy the convenience of buying items anytime, anywhere, but online channels also offer great opportunities for the retailers to sell their products directly to customers all over the world without the need for a physical store $[5,6]$. The advantages are even more obvious in the current pandemic situation, when shopping at physical stores is not convenient. At the same time, e-commerce has increased competition, as more businesses choose to sell their products online [7-9]. Online retailers face some unique challenges compared to those selling their products using the traditional brick and mortar selling model. For example, the delivery time is usually long, customer service is difficult since there is no direct interaction with the customer, and the product, information, and fund transactions heavily rely on e-marketplace platforms and third-party logistics. To remain competitive in the market, it is important for online retailers to understand their supply chain issues and to manage their supply chain effectively in order to reduce costs and to improve customer satisfaction $[10,11]$.

A typical supply chain includes multiple stages, ranging from suppliers, manufacturers, distributors, retailers, and finally, to customers. In the e-commerce supply chain, an 
additional party may be needed to operate an e-marketplace. The different supply chain stages are interconnected to coordinate in terms of the exchange of products, information, and funds to meet the needs of customers [12-14]. If issues are present at any stage in the supply chain, then they could weaken the advantages of e-commerce and block the development of innovation [15]. A systematic view and analysis of all of the activities that are involved will be helpful in identifying issues and in ensuring effective coordination and integration in the supply chain to reduce costs and improve profitability [16,17].

Value stream mapping (VSM) is a lean methodology that can be used to systematically measure, evaluate, and integrate all of the activities that are involved in production processes to achieve a competitive advantage by reducing errors, losses, and lead-time and to improve value-added activities [18]. VSM was originally developed with the lean production movement and has mostly been used in the manufacturing industry. The concept of lean production was introduced by John Krafcik in 1988 [19] and James P. Womack in 1990 [20] as a management principle to elaborate the manufacturing method used by the Toyota Production System (TPS). This management principle has been recognized for its effectiveness in productivity, continuous improvement, product quality, and timely delivery to customers [21-23]. It utilizes graphical tools to show the key elements of a production system as well as the flow of materials and information in the production process. By helping us to understand how activities and operations are connected, VSM lays a basis for the process to be analyzed and drives improvement [24,25]. As the core idea of lean production is maximizing customer value while minimizing waste, which is the same as supply chain management in terms of its philosophical and operational goals and perspectives, we propose to investigate the application of VSM in the analysis of supply chain in e-commerce.

In this paper, the application of VSM in the e-commerce supply chain is explored through a carefully selected e-retailer from Shenzhen, China. The entire supply chain of this e-retailer is visualized using VSM to identify waste. The five whys method is then used to determine the root cause of the waste. The five whys s method is an iterative interrogative technique that can be used to seek the root cause of a problem by asking increasingly granular why questions [26]. Furthermore, a two-stage scoring method based on fuzzy set theory is developed to evaluate and compare the advantages and disadvantages of two different supply chain operation models in order to identify a strategy for improvement. The supply chain process under the new operation model is again visualized using VSM to compare it to the original one. The cost advantage and improvement in the supply chain process are analyzed.

The contribution of this work includes (1) the investigation and adaptation of the application of the lean tool, VSM, in the e-commerce supply chain to systematically assess and analyze the entire supply chain process, from suppliers to customers, to identify potential waste; (2) the integration of the five whys method with VSM to identify the root cause of waste; and (3) the development of a two-stage scoring method to evaluate different operation models. The research provides a systematic approach that can be used to access, evaluate, and improve the e-commence supply chain that can be applied to all common e-businesses.

This paper is organized as follows: In Section 2, we review relevant literature related to e-commerce supply chain management and VSM. In Section 3, we introduce the methodology and the implementation process. In Section 4, we use a carefully selected e-retailer to describe and demonstrate the details of the methodology. The results are analyzed and discussed in Section 5. The implementation of the methodology is concluded and is summarized in Section 6.

\section{Literature Review}

Supply chain management in e-commerce has attracted the attention of professionals and managers worldwide since the 1990s and has been investigated in a number of publications [27]. Early studies on the e-commence supply chain were focused on the structure 
in creating and implementing an integrated e-supply chain system [28-30]. Research then shifted to the operation and management of the e-supply chain after e-commerce merged into the retail market and became more mature. For example, shipping costs and free shipping policies for online retailers were studied in [31,32]. The practical operation of eprocurement was studied in $[33,34]$. Transportation costs were identified as being a critical part of the total logistic costs in e-commerce, and an efficient intermodal transportation auction was proposed in [35]. Channel selection with multiple selling channels and pricing strategies were investigated in [36]. The online scheduling of order batching and delivery were examined in [37]. The influence of consumer channel loyalty and the market power structure to the pricing strategies of online selling were investigated in [38]. The impact of knowledge management and organizational innovativeness on e-commerce supply chain performance was examined in [39,40]. Reference [41] studied the decision making and coordination of an e-commerce supply chain with manufacturer fairness concerns. The implementation status of e-commerce and e-health in the United Kingdom is reviewed in [42]. The e-banking market in Europe was explored in [43]. A recent survey paper by Kumar [44] showed that e-commerce research is expanding to embrace emerging tools, business models, and applications focusing on the vibrant growth in e-commerce. Existing studies on e-commerce supply chain management are mostly focused on a specific issue or stage of the supply chain. There is a lack of a systematic methodology that can be used to assess and evaluate the entire e-commerce supply chain process and to drive improvement.

VSM utilizes graphical tools to show information flow and material flow from raw materials to the deliveries, which provides a systematic view of the processes that are involved in completing a product or a service and drives improvement [18]. VSM is a lean production methodology that was made popular by Rother and Shook in 1999 [45]. As the lean concept is originated from the manufacturing industry, early studies related to VSM focused on theories and practical procedures of VSM in manufacturing sector applications $[18,46,47]$. Inspired by the VSM research in the manufacturing sector and the effectiveness of the methodology, research efforts have implemented VSM in other sectors to achieve improvements in productivity [48]. For example, the application of VSM is explored in the product development process to identify waste, inefficiency, and non-value-added steps [49]. VSM is used to improve environmental sustainability [50-52]. VSM has attracted a great deal of interest in a wide range of service sectors to improve health care efficiency $[53,54]$ and sales processes [55]. The graphical view of VSM helps to understand the processes that are involved in providing a product or service to identify waste, while the five whys method can be used to drill down the root cause of waste. The five whys method is the practice of asking the question of why something is how it is five or more in order to arrive at the root cause of the failure [56]. The method was originally developed by Sakichi Toyoda and was used in the Toyota Motor Corporation during the evolution of its manufacturing methodologies [56,57]. Since then, the method has been widely used in different problem domains because it is very intuitive, easy to apply, and has great adaptivity. The details of the methodology and its implementation procedures can be found in many Lean and Six Sigma handbooks [56]. The five whys method has been proven to be effective in identifying the root causes of failures in many manufacturing and service sector case studies [57-63].

\section{Methodology}

The methodology and the steps taken to assess, evaluate, and improve the e-commerce supply chain are schematically shown in Figure 1. 


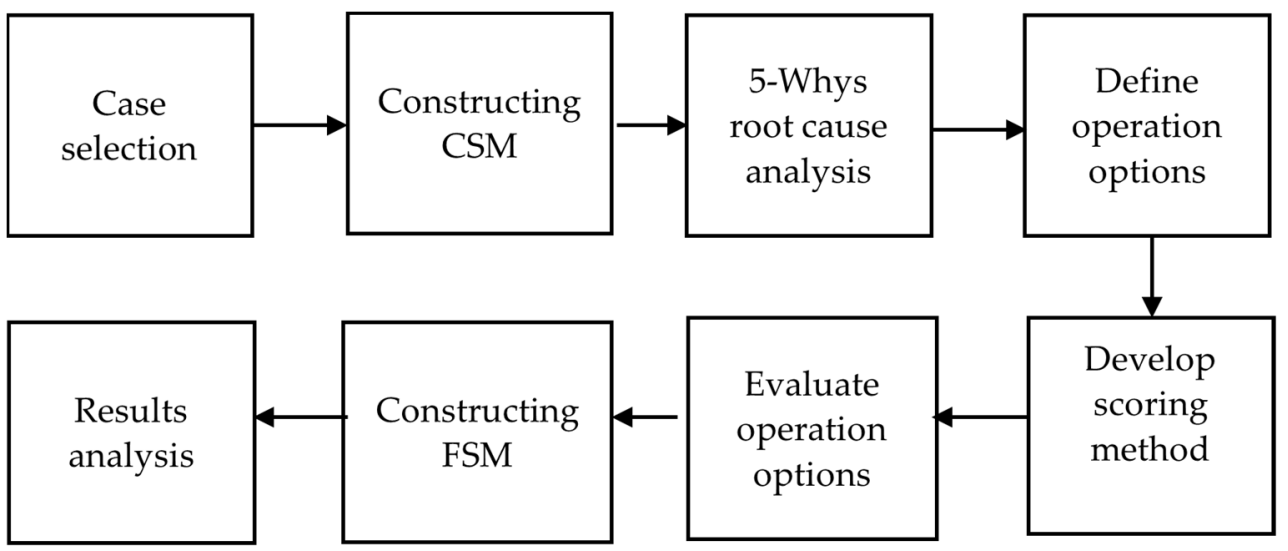

Figure 1. The methodology flow chart of the analysis processes.

\subsection{Case Selection}

In the e-commerce supply chain, business owners choose from two options through which they can sell their products online: (1) a business develops its own website where all transactions take place between the business organization and consumer directly or (2) a business sells its products on an online marketplace where the information infrastructure has been built and is owned by a third party. The second option is often the first choice for small- to medium-sized businesses whose sales volume is not big enough to justify the cost of building their own online website. Among many online marketplaces, Amazon is the world's largest one and is continuing to attract more and more customers [64,65]. Small and medium businesses who sell their products on Amazon are from the US as well as from more than 130 countries around the world. Their products account for more than $50 \%$ of all units sold on Amazon [66]. Those businesses need support and guidance for high-quality supply chain management. In this study, a case-based approach $[67,68]$ is used to demonstrate our methodology. As a representative study case, a small product retailer who sells products on Amazon was selected. The retailer is based in Shenzhen, China, and it entered into the North American market through the Amazon platform in July 2019. The retailer currently has 10 employees, with yearly sales that are close to 3 million dollars. The e-retailer faces challenges such as slow sales growth, long delivery times, and low customer satisfaction, which are typical issues in e-commerce.

\subsection{Value Stream Mapping}

After the case was selected, VSM was applied to analyze the supply chain process of the e-retailer. VSM classifies all of the activities of a production process into three categories: value-added (VA), necessary but non-value-added (NNVA), and non-value-added and unnecessary (NVA) [21]. The goal of VSM is to make the flow of products, information, and funds efficient by reducing NNVA activities and by removing NVA activities in a timely manner and to improve value-creating time. There are three basic steps in applying VSM: constructing a current state map (CSM), constructing a future state map (FSM), and formulating an action plan [18]. VSM utilizes symbols to represent different parties and activity links and flows of a production process $[25,69]$. The symbols that were used during the creation of the VSM for this case study and their meanings are listed in Table 1 . All of the VSM-related graphs in this paper were produced using the Microsoft product "Smartdraw". 
Table 1. Symbols and the meanings of the symbols used to construct the VSM.

\begin{tabular}{ccc}
\hline No. & Symbol & Meaning \\
\hline 1 & Supplier or Customer \\
2 & Process Control or Process \\
4 & & Inventory \\
5 & & External Shipping \\
6 & & Material Flow \\
\hline
\end{tabular}

\section{Case Study}

The main products of the selected retailer include phone cases, power strips, puppy pads, party decorations, cordless jump ropes, and automatic soap dispensers. Their bestselling products, phone cases and party decorations, will be used in this case study. The retailer places weekly replenishment orders to its suppliers, and the inventory is kept at its office in Shenzhen, China, and it is from here that the products are shipped to their customers. As more and more retailers are entering into the online market, the competition is becoming more intense. The e-retailer is striving to improve their supply chain operations, reduce costs, and increase customer satisfaction to be competitive in the market.

\subsection{Current Stream Mapping (CSM)}

In this section, the CSM is constructed to exhibit the entire supply chain process of the two selected products: phone cases and party decorations, as shown in Figure 2.

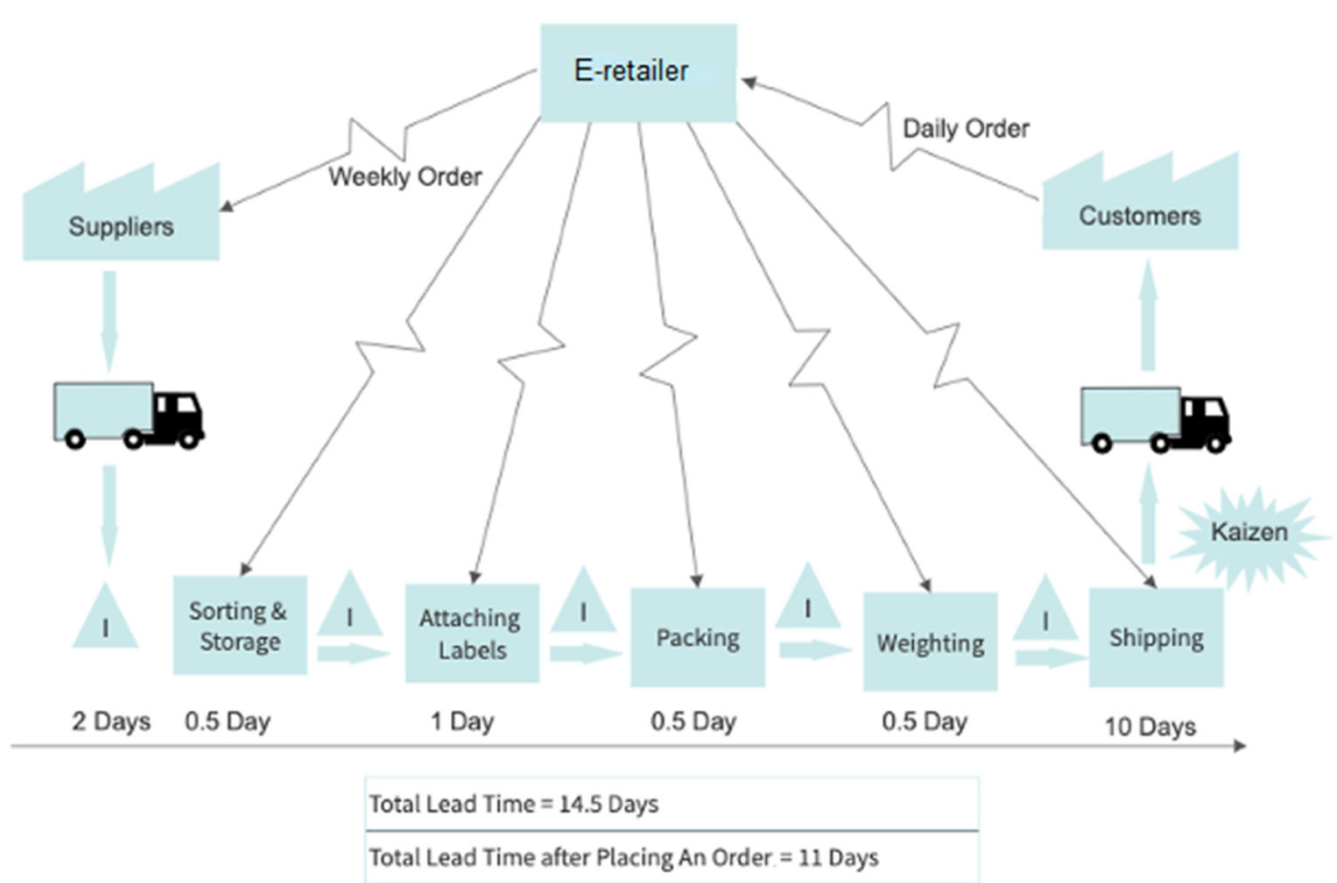

Figure 2. The current VSM of the phone case supply chain in the e-retailer.

The e-retailer places a weekly replenishment order to its suppliers. The order is shipped to the retailer's office to be inventoried by a logistics company, which takes 2 days. It takes 1.5 days for the received raw products to be sorted and stored by the employees of 
the e-retailer. During this process, the products are packaged, the logo of the e-retailer is printed on the products, and a scanning label is attached to each package. The products are then made available on Amazon's official website for sale. Customer orders arrive on a daily basis. Upon receiving an order, the needed items are packed and weighted at the e-retailer, which takes 1 day in total. The e-retailer uses an online logistics platform operated by 4PX (Shenzhen, China), to select a contracted external logistics company, such as Federal Standard Shipping or Henan E Post, etc., to pick up the packages and to handle the final delivery. The e-retailer chose an economical air mail delivery method due the attributes of their products being small and lightweight. It takes 10 days on average to deliver an order to a customer. Thus, the response time to customers is 11 days, which is $76 \%$ of the total time a product is in the e-retailer supply chain process. The response time has the highest potential to be reduced and may be the source of NNVA and NVA activities in this value stream.

\subsection{Five-Whys Root Cause Analysis}

The five whys method was employed to drill down the root cause of the potential waste. Starting from essential questions regarding low sales, a series of "why" questions were asked and solutions to address these questions were generated, as shown in Table 2. Usually, there are multiple answers or causes for a given question. The causes of the questions should be discussed among a cross-functional business management team, and a conclusion should be supported by concrete data analysis. In this case study, the cause was identified based on feedback received from customers and through the brainstorming of the supply chain management team. For example, the low sales volume was due to low customer satisfaction, and the cause was supported by many customer complaints regarding the response time. The ultimate solution to the issue was to find a business partner in US, where the majority of the customers were located, to handle the inventory storage and order delivery. By moving inventories to a local warehouse that is closer to the customers, the response time could be greatly reduced to improve customer satisfaction, which would lead to sales growth.

Table 2. Analysis process of the five whys method and the resulting solutions.

\begin{tabular}{cc}
\hline Question & Cause \\
\hline $\begin{array}{c}\text { Why is the sales volume low? } \\
\text { Why is the response time long? }\end{array}$ & $\begin{array}{c}\text { The customers are not happy with the long response time } \\
\text { The delivery time is long }\end{array}$ \\
Why is the delivery time long? & $\begin{array}{c}\text { The inventory is kept too far from the customer } \\
\text { Reduce delivery time }\end{array}$ \\
Why is the inventory kept far from the customers? & $\begin{array}{c}\text { The warehouse is in China, and the customers are in the USA. } \\
\text { The company does not have a warehouse or any partners in } \\
\text { the USA. }\end{array}$ \\
\hline
\end{tabular}

\subsection{Scoring Method for Logistic Model Selection}

There are typically two overseas logistic operation options for an Amazon e-retailer to consider: (1) Use the services provided by Amazon, called fulfillment by Amazon (FBA) or (2) use the services provided by other logistics companies, called fulfillment by a third-party logistics (FB3PL) [70-72]. In the FBA option, the suppliers of the retailer ship the goods directly to the Amazon warehouse in the US. The products will be listed on Amazon's website once they are available in the Amazon warehouse. Amazon will pack and ship the products to the customer once an order is received. In the FB3PL option, an 3PL company in the US will be selected to provide services that include warehousing, sorting, packaging, and delivering. As each of the two options has their unique service features to offer, making a side-by-side comparison is not straight forward. In order to effectively and efficiently select an option that best fits the logistic needs of the retailer, a two-stage scoring method is developed to evaluate the options. In the first stage, a fuzzy Delphi method (FDM) is designed to identify key logistic factors. In the second stage, the key logistic factors are 
mapped to the service features that each option offers, and an overall score is obtained for each option by collecting expert opinions. The option with the highest score will be selected.

\subsubsection{Stage I-Determination of the Key Logistic Factors}

There are many logistic factors to be considered in the supply chain. The importance of these factors is different for each individual business due to different development strategies and the different characteristics of businesses. Delphi is a method that utilizes multiple questionnaires to integrate the opinions of experts to identify key factors [73]. To consolidate important logistic factors for the selection of a logistics operation model for the retailer, we designed a fuzzy Delphi method (FDM) that utilizes fuzzy set theory to obtain a fuzzy number for each logistic factor to determine the key logistic factors. The method will expedite the convergence of opinions in the second stage and will facilitate the final selection of the logistic operation option. The FDM is constructed through the following steps:

1. Propose potential important logistic factors to be considered, as shown in Table 3. Other than the common important logistic factors such as cost, on-time delivery, etc., warehouse location was included, as the distance between the warehouse and customer has a direct impact on delivery time. Sales growth indicates whether a partner can help the e-retailer to increase sales. Responsiveness refers to the adaptivity to the changes of industry-related policies, rules, and terms.

2. Assign linguistic terms that indicate the importance level of the proposed logistic factors with their associated reference fuzzy numbers, as shown in Table 4. Fuzzy numbers were introduced by Zadeh in order to deal with imprecise numerical quantities in a practical way [74]. Rather than assigning an exact importance number to each logistic factor, the fuzzy number allows the importance of the logistic factors to be expressed as a range between 0 and 1, which is more practical. For example, the importance of a logistic factor can be given a triangular fuzzy number of $(0.4,0.6,0.8)$, with 0.6 being assigned to indicate that the factor is important in an ordinary situation, with 0.4 or 0.8 representing the most conservative or optimistic consideration, respectively. The proposed logistic factors along with Table 4 were sent to eight experts as questionnaires to collect the scores for each logistic factor. All of the experts have been in supply chain management positions in the e-retail industry for at least 4 years.

3. Calculate fuzzy weight/importance score for each logistic factor based on the scores received from the experts. The calculation process is as follows: The importance score of factor $j$ evaluated by expert $i$ is denoted as $f_{i j}=\left(a_{i j}, b_{i j}, c_{i j}\right)$ for $i=1,2, \ldots, 8 ; j=1,2, \ldots 10$. The fuzzy weight of factor $j$ is denoted as $f_{j}=\left(a_{j}, b_{j}, c_{j}\right)$, where $a_{j}=\min \left\{a_{i j}\right\}$, $b_{j}=\left(\prod_{i=1}^{n} b_{i j}\right)^{1 / n}, c_{j}=\max \left\{c_{i j}\right\}$. The extreme values that fall outside two standard deviations are removed.

4. Compare the fuzzy weight score of each factor with a threshold $\widetilde{f}$ to identify key logistic factors, where $\widetilde{f}=\left\{\right.$ average $\left(a_{j}\right)$, average $\left(b_{j}\right)$, average $\left.\left(c_{j}\right)\right\}$, the average values of the weight of all factors. A factor $j$ with $f_{j} \geq \tilde{f}$ will be selected, while a factor with $f_{j}<\tilde{f}$ will be rejected. The fuzzy weight/importance score for each logistic factor, the threshold $\widetilde{f}$, and the decision for each logistic factor are shown in Table 5. By comparing the Fuzzy weight with the threshold, six out of ten logistic factors are identified as key logistic factors and are selected.

Table 3. Evaluation factor for overseas warehouse selection.

\begin{tabular}{ll}
\hline & Factors \\
\hline Cost & Logistics information system \\
Warehouse location & Customer service \\
Sales growth & Capability to fill emergency orders \\
Logistics equipment & Responsiveness \\
Optimization capabilities & On time delivery \\
\hline
\end{tabular}


Table 4. Linguistic terms and the corresponding triangular fuzzy numbers.

\begin{tabular}{cc}
\hline Linguistic Term & Fuzzy Number \\
\hline Very Unimportant & $(0,0,0.2)$ \\
Moderately Unimportant & $(0,0.2,0.4)$ \\
Unimportant & $(0.2,0.4,0.6)$ \\
Important & $(0.4,0.6,0.8)$ \\
Moderately Important & $(0.6,0.8,1)$ \\
Very Important & $(0.8,1,1)$ \\
\hline
\end{tabular}

Table 5. Results from FDM.

\begin{tabular}{ccc}
\hline Factors & Fuzzy Weight & Decision \\
\hline Price & $(0.4,0.765542,1)$ & Selected \\
Warehouse location & $(0,0.391595,0.8)$ & Rejected \\
Sales growth & $(0.6,0.919727,1)$ & Selected \\
Logistics equipment & $(0,0.259368,0.6)$ & Rejected \\
Optimization capabilities & $(0,0.224492,0.6)$ & Rejected \\
Logistics information system & $(0.4,0.621969,1)$ & Selected \\
Customer service quality & $(0.6,0.862835,1)$ & Selected \\
Capability to fill emergency orders & $(0,0.297548,0.6)$ & Rejected \\
Responsiveness & $(0.2,0.626034,1)$ & Selected \\
On-time delivery & $(0.4,0.787196,1)$ & Selected \\
Threshold & $(0.272727,0.588590,0.872727)$ & \\
\hline
\end{tabular}

\subsubsection{Stage II: Scoring Logistic Operation Models}

The key factors identified in the first stage are mapped to the service features offered by FBA and 3PL to provide a direct link between them, and a second questionnaire was then developed during this stage. In the second stage questionnaire, each service feature is scored by the retailer's management team, the advantages and disadvantages of the two options are compared, and a final score is obtained for each. The scoring criteria in this stage reference a four-quadrant method, a simple scoring methodology that is suitable for business managers who may have limited knowledge of detailed logistic terms. The four-quadrant scoring criteria are shown in Table 6. A scoring range of 1 to 5 was used to reflect the urgency and importance of the advantages and disadvantages of the services. For urgent and important features, a score of 5 is applicable. For not urgent but important or urgent but not important features, a score of 3 is applicable. A score of 1 can be given to service features that are neither important nor urgent.

Table 6. Four-quadrant scoring criteria.

\begin{tabular}{ccc}
\hline Score & Urgent & Not Urgent \\
\hline Very important & 5 & 3 \\
Important & 3 & 1 \\
\hline
\end{tabular}

The advantages and disadvantages of the service features from FBA and 3PL and their associated logistic factors are provided in the first two columns of Tables 7-10. The tables were sent to the e-retailer management team as questionnaires. The management team evaluated and assigned a score to each service feature based on the scoring criteria provided in Table 6. A high score, depending on the service feature being an advantage or a disadvantage, represents that the impact is significantly positive or negative to the e-retailer. The scores that were collected from the e-retailer management team are shown in the last column of Tables 7-10.

The overall scores for FBA and 3PL are summarized in Table 11. The logistic operation model for FBA has a total score of 22 for advantages and 11 for disadvantages. The logistic operation model for 3PL has a total score of 16 for advantages and 22 for disadvantages. 
The FBA model has a higher score in terms of advantages and a lower score in terms of disadvantage, and it outperforms the 3PL model in both aspects. The improvement in customer satisfaction and sales growth are the two most important objectives of the e-retailer. The two-day delivery and $24 \times 7$ customer service offered by the FBA model help the e-retailer to achieve such goals. In addition, some unique service features offered by Amazon, such as Amazon's trusted customer service and returns and strategies to improve listing rank and customer flow may help attract even more customers [75].

Table 7. Advantages of FBA, their corresponding logistic factors, and scores.

\begin{tabular}{|c|c|c|}
\hline \multicolumn{3}{|l|}{ FBA } \\
\hline Advantages & Relative Factors & Score \\
\hline Fast order fulfillment: 2-day delivery for Prime members & $\begin{array}{l}\text { Customer service quality, sales growth, } \\
\text { responsiveness, on-time delivery }\end{array}$ & 5 \\
\hline Direct access to prime customers & Sales growth & 3 \\
\hline Customer support: $7 \times 24$ h customer service, complaints, and returns & $\begin{array}{l}\text { Customer service quality, sales growth, } \\
\text { responsiveness }\end{array}$ & 3 \\
\hline $\begin{array}{l}\text { Transparent and simple fee structure: providing a handy calculator for } \\
\text { sellers calculating their fees }\end{array}$ & Logistics information system & 1 \\
\hline $\begin{array}{l}\text { High purchase rate: customers trust Amazon and are more willing to buy } \\
\text { product fulfilled by Amazon }\end{array}$ & Sales growth & 5 \\
\hline Prime promotion and other Amazon boosts: Improving product listing rank & Sales growth & 5 \\
\hline Total score & & 22 \\
\hline
\end{tabular}

Table 8. Disadvantages of FBA, their corresponding logistic factors, and scores.

\begin{tabular}{|c|c|c|}
\hline \multicolumn{3}{|l|}{ FBA } \\
\hline Disadvantages & Relative Factors & Score \\
\hline Little order customization: must follow existing Amazon processes, poor flexibility & Responsiveness & 1 \\
\hline Higher overall fees: higher long-term storage fee, order handling fee & Price & 3 \\
\hline Low company brand exposure: products packed in Amazon-branded box & Responsiveness & 3 \\
\hline Returns and exchanges are biased towards customers: products waste & Price & 1 \\
\hline Little customer interaction: & Customer service quality & 3 \\
\hline Total score & & 11 \\
\hline
\end{tabular}

Table 9. Advantages of 3PL, their corresponding logistic factors, and scores.

\begin{tabular}{|c|c|c|}
\hline \multicolumn{3}{|c|}{ 3PL } \\
\hline Advantages & Relative Factors & Score \\
\hline B2B and B2C fulfillment, supporting different sales channels & Sales growth, responsiveness & 3 \\
\hline Customization for customers: value added services & Customer service quality, responsiveness & 3 \\
\hline Customization for sellers: customized seller branded packing & Customer service quality, responsiveness & 3 \\
\hline Low overall fees: low storage fee, order handling fee & Price & 3 \\
\hline Various options: a wide variety of 3PLs & Price & 3 \\
\hline Customs clearance service & Customer service quality, responsiveness & 1 \\
\hline Total score & & 16 \\
\hline
\end{tabular}

Table 10. Disadvantages of 3PL, their corresponding logistic factors, and scores.

\begin{tabular}{lll}
\hline \multicolumn{1}{c}{ Disadvantages } & 3PL & \multicolumn{1}{c}{ Relative Factors } \\
\hline Not friendly for unstable or small order volume & Score \\
Initial fees: setup fee, receiving fee & 3 \\
Not easy to find a trustworthy 3PL company & Price, logistics information system \\
No impact on sales & Customer service quality \\
Slower delivery speeds: no 2-day shipping guarantee & Sales growth \\
Customs clearance service & Customer service quality, on-time delivery, \\
Total score & responsiveness & Logistics information system \\
\hline
\end{tabular}


Table 11. Summary of the overall scoring results for FBA and 3PL.

\begin{tabular}{ccccc}
\hline & \multicolumn{2}{c}{ FBA } & \multicolumn{2}{c}{ 3PL } \\
\cline { 2 - 5 } & Score & Proportion & Score & Proportion \\
\hline Advantages & 22 & $67 \%$ & 16 & $44 \%$ \\
Disadvantages & 11 & $33 \%$ & 20 & $56 \%$ \\
\hline Total & 33 & $100 \%$ & 36 & $100 \%$ \\
\hline
\end{tabular}

\subsection{Future Stream Mapping (FSM)}

In this section, the FSM is constructed to view the entire supply chain process with the adoption of the FBA logistic model, as shown in Figure 3.

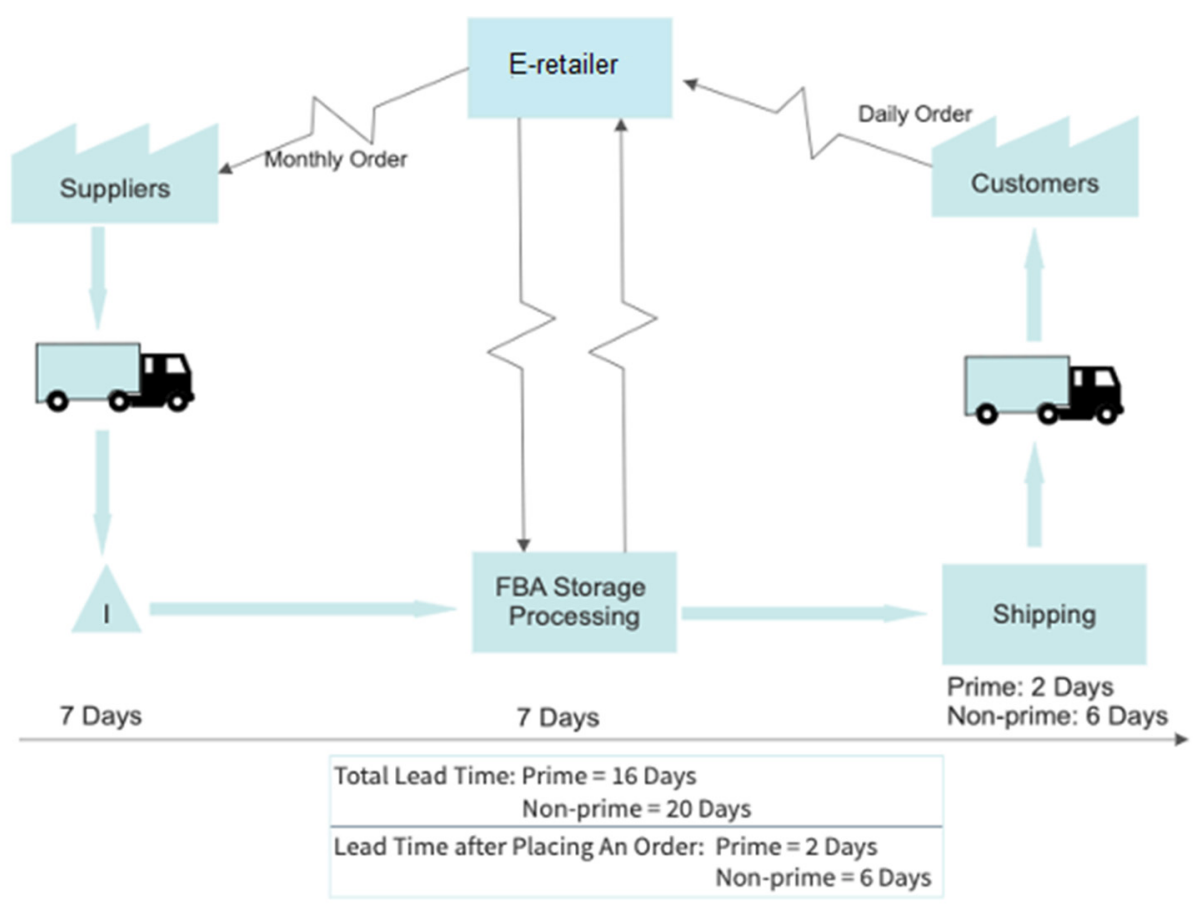

Figure 3. The future VSM with FBA model applied for the e-retailer.

The e-retailer places a monthly replenishment order instead of a weekly order to its suppliers. The retailer entrusts the supplier to package the products, including attaching the logo and the scanning label, and the supplier sends the products directly to the Amazon warehouse in the United States. The supplier uses a third-party logistic carrier, and an average of 7 days are expected for the above processes after an order is placed by the retailer. After the products arrive at the Amazon warehouse, another 7 days are needed for the Amazon employees to sort and process the products in the storage space. The products are then ready to go on the market. Upon receiving an order, Amazon employees will pick and pack the products and manage the final delivery. This process takes an average of 2 days for Amazon Prime members, and 6 days for non-Prime members. The total time of a product in the e-retailer supply chain process is 16 or 20 days, which is longer than it is in CSM. The response time to customers is reduced from 11 days to 2 days or 6 days depending on the customer's membership status. The significant reduction in the response time will likely contribute to improvements in customer satisfaction and sales growth. It also shows that the NVA activities, such as sorting, storage, attaching labels, packing, and weighting are better organized. The replenishment orders to the suppliers and shipments to the warehouse in the US are consolidated and streamlined, which can further reduce costs. A cost comparison before and after the adoption of the FBA logistic model will be 
conducted in the next section using the two selected products, i.e., mobile phone cases and party decorations.

\subsection{Cost Analysis}

Costs are calculated based on the average monthly sales of the two selected products over the past 6 months at the time of this study, which are 200 units and 48 units per month, respectively, for mobile phone cases and party decorations.

Under the original logistics operation model, called fulfillment by retailer (FBR), the costs include shipping costs from suppliers to the e-retailer, shipping costs from the eretailer to the customers, and labor costs. There are no additional costs for inventory under FBR, as the product size is small and the demand is low, and the products are kept at their local office in Shenzhen. The cost of the products and Amazon referral fees for using Amazon platform are the same as before and after the adoption of the FBA and are thus excluded from calculation of the total costs for both models. The weekly shipping costs from the suppliers to the e-retailer are shown in Table 12, Part 1, where the calculation is based on a weekly replenishment order of 50 and 12, respectively, for the two products and a weight-based shipping charge. The shipping costs from the e-retailer to the customers for the two products are unit based and are shown in Table 12, Part 2. An average shipping charge per unit based on quotes from three logistic companies on 4PX is used for the calculation of total shipping cost. The monthly labor cost needed at the e-retailer for activities such as sorting, packing, weighing, and labeling, etc., are estimated to be CNY 3000 and CNY 1500 based on employee salaries and the hours needed for mobile phone case and party decorations, respectively.

Table 12. FBR-Weekly replenishment shipping cost (Part 1 ) and unit shipping cost from e-retailer to customers (Part 2).

\begin{tabular}{|c|c|c|c|c|c|c|c|}
\hline \multicolumn{8}{|c|}{ Part 1: From Supplier to e-Retailer } \\
\hline \multirow{2}{*}{ Product } & \multirow{2}{*}{$\begin{array}{c}\text { Unit } \\
\text { weight } \\
\text { (kg/unit) } \\
\text { a }\end{array}$} & \multirow{2}{*}{$\begin{array}{l}\text { Weekly } \\
\text { quantity } \\
\text { (unit) } \\
\text { b }\end{array}$} & \multirow{2}{*}{$\begin{array}{c}\text { Packing } \\
\text { weight } \\
\text { (kg) } \\
\text { c }\end{array}$} & \multirow{2}{*}{$\begin{array}{c}\text { Total } \\
\text { weight } \\
(\mathrm{kg}) \\
\mathrm{d}=\mathrm{a} \times \mathrm{b}+\mathrm{c}\end{array}$} & \multicolumn{2}{|c|}{$\begin{array}{c}\text { Charges } \\
(\mathrm{CNY} / \mathrm{kg})\end{array}$} & \multirow{2}{*}{$\begin{array}{l}\text { Shipping cost } \\
(\mathrm{CNY} / \text { week }) \\
\mathrm{g}=\mathrm{e}+(\mathrm{d}-1) \times \mathrm{f}\end{array}$} \\
\hline & & & & & $\begin{array}{c}\text { First } 1 \mathrm{~kg} \\
\mathrm{e}\end{array}$ & $\underset{f}{\text { Rest kgs }}$ & \\
\hline Phone case & 0.11 & 50 & 0.5 & 6 & 10 & 7 & 45 \\
\hline Party decorations & 0.27 & 12 & 0.5 & 3.74 & 10 & 7 & 29.18 \\
\hline \multicolumn{8}{|c|}{ Part 2: From E-retailer to Customer } \\
\hline & \multicolumn{3}{|c|}{ Unit weight (kg/unit) } & \multicolumn{4}{|c|}{ Charges (CNY/unit) } \\
\hline Product & $\begin{array}{l}\text { Product } \\
\text { weight } \\
\text { a }\end{array}$ & $\begin{array}{c}\text { Packing } \\
\text { weight } \\
\text { b }\end{array}$ & $\begin{array}{c}\text { Total } \\
\text { weight } \\
\mathrm{c}=\mathrm{a}+\mathrm{b}\end{array}$ & $\begin{array}{l}\text { Option } 1 \\
\mathrm{~d}\end{array}$ & $\begin{array}{c}\text { Option } 2 \\
\mathrm{e}\end{array}$ & $\begin{array}{c}\text { Option } 3 \\
\mathrm{f}\end{array}$ & $\begin{aligned} & \text { Average } \\
& (¥ / \text { unit }) \\
\mathrm{g}= & (\mathrm{d}+\mathrm{e}+\mathrm{f}) / 3\end{aligned}$ \\
\hline Phone case & 0.11 & 0.01 & 0.12 & 25.30 & 27.60 & 28.48 & 27.13 \\
\hline Party decorations & 0.27 & 0.02 & 0.29 & 38.78 & 41.81 & 41.81 & 40.80 \\
\hline
\end{tabular}

Under FBA, costs include shipping costs from the supplier to the Amazon warehouse, inventory costs, and a product-varying FBA fee that Amazon charges to cover customer delivery and overhead. The cost of the products and Amazon referral fees for using the Amazon platform are once again not included, as they are the same for both operation models. The monthly shipping costs for the two products under the FBA are shown in Table 13. Under this scenario, an external logistics company provides a quote for the entire package based on the product type and weight. An averaged shipping charge based on quotes from three logistic companies is used. The monthly inventory cost and FBA fee per unit can be found from Amazon Seller Central by selecting the corresponding product category, package size, and average inventory units. Amazon charges USD 0.01/unit for inventory and USD 3.31/unit FBA fee for mobile phone cases and USD 0.04/unit for inventory USD 3.48/unit FBA fee for party decorations [75]. 
Table 13. FBA-Monthly shipping cost from supplier to Amazon warehouse for P1 and P2.

\begin{tabular}{|c|c|c|c|c|c|c|c|c|}
\hline \multicolumn{9}{|c|}{ Part 3: From Supplier to FBA Warehouse } \\
\hline & \multicolumn{4}{|c|}{ Weight } & \multicolumn{4}{|c|}{ Charges (CNY) } \\
\hline \multirow{2}{*}{ Product } & \multirow{2}{*}{$\begin{array}{c}\text { Unit } \\
\text { product } \\
\text { weight } \\
\text { (kg/unit) } \\
\text { a }\end{array}$} & $\begin{array}{l}\text { Monthly } \\
\text { quantity }\end{array}$ & $\begin{array}{l}\text { Packing } \\
\text { weight }\end{array}$ & Total weight & Option 1 & Option 2 & Option 3 & Average \\
\hline & & $\begin{array}{l}\text { (unit) } \\
\text { b }\end{array}$ & $\underset{\mathrm{C}}{(\mathrm{kg})}$ & $\begin{array}{c}(\mathrm{kg}) \\
\mathrm{d}=\mathrm{a} \times \mathrm{b}+\mathrm{c}\end{array}$ & $\mathrm{e}$ & $\mathrm{f}$ & g & $h=(e+f+g) / 3$ \\
\hline Phone case & 0.11 & 200 & 1.5 & 23.50 & 1251.03 & 1434.90 & 1483.00 & 1389.63 \\
\hline Party decorations & 0.27 & 48 & 2 & 14.96 & 1040.35 & 1238.43 & 1410.00 & 1229.59 \\
\hline
\end{tabular}

The total monthly costs before and after the adoption of the FBA logistic model for the two products are shown in Table 14. The total costs under FBR are the summation of the weekly shipping costs multiplied by 4 weeks, the unit shipping cost multiplied by the average monthly sales in units, and the monthly labor cost for each product. The total cost under FBA is the summation of the monthly shipping cost, the unit FBA fee multiplied by average monthly sales in units, and the unit inventory cost multiplied by the cycle inventory, which is half of the average monthly sales in units for each product. The currency exchange rate USD $1=$ CNY 6.51 according to the published market rate at the time of this research was used to convert the Chinese currency to US dollars [76]. By comparing the total costs of the two logistic operation models as shown in Table 14, it can be observed there is a cost advantage that can be incurred by adopting the new FBA model based on the current levels of demand.

Table 14. Total monthly cost FBR vs. FBA.

\begin{tabular}{|c|c|c|c|c|c|}
\hline \multirow{2}{*}{\multicolumn{2}{|c|}{$\begin{array}{l}\text { Product } \\
\text { Model }\end{array}$}} & \multicolumn{2}{|c|}{$\begin{array}{l}\text { Phone Case } \\
\text { QTY = } 200\end{array}$} & \multicolumn{2}{|c|}{$\begin{array}{l}\text { Party Decorations } \\
\text { QTY }=48\end{array}$} \\
\hline & & FBR & FBA & FBR & FBA \\
\hline \multirow{3}{*}{ Shipping cost (USD) } & Supplier to e-retailer & 27.65 & / & 17.93 & / \\
\hline & E-retailer to Customer & 833.49 & / & 300.83 & / \\
\hline & Supplier to FBA & / & 213.46 & / & 188.88 \\
\hline \multirow{2}{*}{ Fulfillment cost (USD) } & Labor cost & 460.83 & / & 230.41 & / \\
\hline & FBA fee & / & 662.00 & / & 167.04 \\
\hline \multicolumn{2}{|c|}{ Inventory cost (USD) } & / & 1.00 & / & 0.96 \\
\hline \multicolumn{2}{|c|}{ Total cost (USD) } & 1321.97 & 876.46 & 549.17 & 356.88 \\
\hline
\end{tabular}

\section{Results and Discussion}

By switching to the new FBA logistic operation model, the weekly replenishment orders are aggregated into a monthly order to be shipped to the warehouse in US, and the international shipping of each individual customer order from the e-retailed is replaced by a local shipping from the warehouse in the US. The monthly costs related to the replenishment are increased from USD 27.65 to USD 213.46 for mobile phone cases and from USD 17.93 to USD 188.88 for party decorations due to international shipping, as shown in Table 14. The cost for each individual customer order is reduced from $833.49 / 200=$ USD $4.17 /$ unit to $(662+1) / 200=$ USD 3.32/unit for mobile phone cases and from $300.83 / 48=$ USD $6.27 /$ unit to $(167.04+0.96) / 48=$ USD $3.5 /$ unit for party decorations. The cost increase in replenishment is a one-time event in a month, while the cost benefits that are associated with each customer order increase linearly with sales. The cost advantage of the new logistic model will be more significant as the sales continue to increase in the future.

Based on the analysis and results from our methodology, the e-retailer adopted the FBA logistic model in September 2020. The sales volumes in terms of the monthly, 3-month average, and 6-month average from July 2019 to March 2021 are plotted in Figure 4. There was a slight increasing trend in sales from July 2019 to August 2020 when using the original 
operation model, while rapid sales growth was observed following the adoption of the FBA logistic model in September 2020. The sales of mobile phone cases increased by $67 \%$, from 95 units in August 2020 to 159 units in September 2020. The sales of party decorations increased by 72\%, from 25 units in August 2020 to 43 units in September 2020. No customer complaints regarding the response time were reported after the implementation of the FBA logistic model.

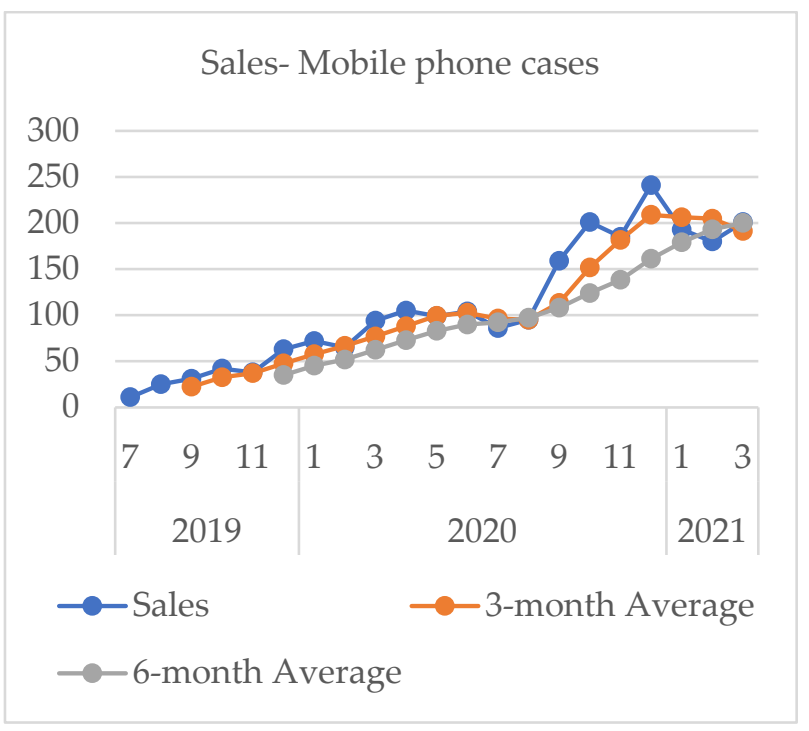

(a)

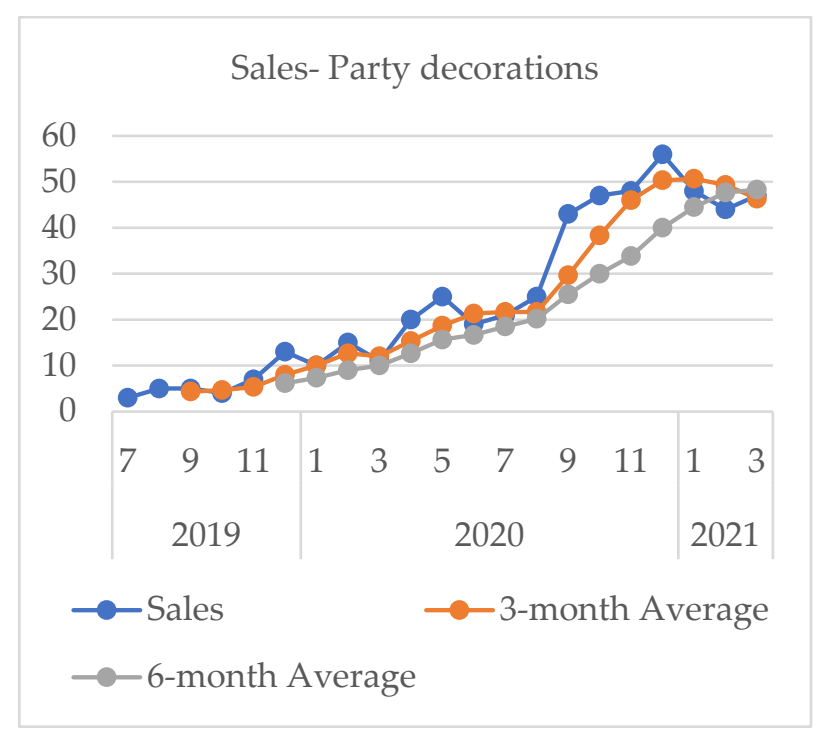

(b)

Figure 4. Monthly, 3-month average, and 6-month average for (a) mobile phone cases and (b) party decorations.

\section{Conclusions}

Recently, e-commerce has become one of the most important pillars of economy, and the e-commerce supply chain is continuously being improved to increase efficiency and to reduce costs. One important part of successful supply chain management is the ability to visualize each link in the supply chain $[69,77]$. In this paper, we developed an easyto-follow methodology to systematically assess, evaluate, and the improve e-commerce supply chain by utilizing VSM. The methodology has some novel features that contribute to the existing research and industry practitioners.

First, the methodology integrates VSM, the five why method, and a scoring system into a systematic tool that visualizes supply chain process, identifies waste and root causes, and provides solutions for industry practitioners.

Second, a two-stage scoring method was designed to evaluate the supply chain operation options. The first stage of the scoring system utilizes fuzzy set theory that allows the importance of the logistic factors to be expressed as a range between 0 and 1, which is more practical. The key factors that were identified in the first stage are mapped to service features offered by different logistic operation models. This makes the service features more intuitive to business managers who may have limited knowledge of detailed logistic terms and facilitates the final evaluation of each logistic operation model. A simple yet effective four-quadrant scoring methodology was then used in the second stage to obtain final scores for different logistic operation models. The methodology is demonstrated through a typical Amazon e-retailer case study. The parties and activities involved, the links in-between, and the flow of information and products in the supply chain process are visualized through the construction of the VSM. The entire supply chain process flow is better understood, and the potential waste is easily identified. The root cause of the waste was then determined using the five whys method. The two-stage scoring method was used to evaluate and compare 
two logistic models to identify a strategy for improvement. The methodology is effective in improving e-commerce supply chain efficiency, customer satisfaction, and cost reductions.

Our methodology may have some limitations, as it was only applied to a small-scale eretailer with a simple supply chain structure. In this study, all of the lead time and shipping costs were considered to be fixed, and only the scenario of one supplier was assessed, and average monthly sales were used to calculate the total costs. Our methodology may need to be adapted to more sophisticated supply chain scenarios. In the future, we plan to extend the scope of the case study and to explore other functionalities that VSM could offer. In addition, as supply chain and logistic issues deteriorate under prolonged pandemic conditions in different service sectors, we plan to explore the application of the proposed methodology to improve health care efficiency and other general supply chain problems.

Author Contributions: Conceptualization, Y.Q. and H.L.; data curation, Y.Q.; formal analysis, Y.Q. and H.L.; methodology, Y.Q. and H.L.; supervision, H.L.; writing-original draft, Y.Q. and H.L.; writing-review \& editing, H.L. All authors have read and agreed to the published version of the manuscript.

Funding: This research received no external funding.

Institutional Review Board Statement: Not applicable.

Informed Consent Statement: Not applicable.

Data Availability Statement: Data is contained within the article.

Conflicts of Interest: The authors declare no conflict of interest.

\section{References}

1. Gregory, G.D.; Ngo, L.V.; Karavdic, M. Developing e-commerce marketing capabilities and efficiencies for enhanced performance in business-to-business export ventures. Ind. Mark. Manag. 2019, 78, 146-157. [CrossRef]

2. Forbes. Available online: https://www.forbes.com/sites/michelleevans1/2021/03/25/global-e-commerce-market-to-expandby-us1-trillion-by-2025/?sh=13ef9bd76cc0 (accessed on 28 November 2021).

3. Lim, W.M. History, lessons, and ways forward from the COVID-19 pandemic. Int. J. Qual. Innov. 2021, 5, 101-108.

4. Forbes. Available online: https://www.forbes.com/sites/michelleevans1/2021/01/19/five-e-commerce-trends-that-willchange-retail-in-2021/?sh=6d7b24e81435 (accessed on 28 November 2021).

5. Rahimzadeh, F.; Heydari, M. A review of ecommerce competitive advantages in international trade. UJMAS 2017, 5, 79-85. [CrossRef]

6. Sabou, S.; Avram-Pop, B.; Zima, L.A. The impact of the problems faced by online customers on ecommerce. Stud. Univ. Babes-Bolyai Oecon. 2016, 62, 77-88. [CrossRef]

7. Bradlow, E.T.; Gangwar, M.; Kopalle, P.; Voleti, S. The role of big data and predictive analytics in retailing. J. Retail. 2017, 93, 79-95. [CrossRef]

8. Xu, X.; Munson, C.L.; Zeng, S. The impact of e-service offerings on the demand of online customers. Int. J. Prod. Econ. 2017, 184, 231-244. [CrossRef]

9. Sharma, A.; Liu, H.; Liu, H. Best Seller Rank (BSR) to Sales: An empirical look at Amazon. com. In Proceedings of the 2020 IEEE 20th International Conference on Software Quality, Reliability and Security, Macau, China, 11-14 December 2020. [CrossRef]

10. Varoutsa, E.; Scapens, R.W. The governance of inter-organisational relationships during different supply chain maturity phases. Ind. Mark. Manag. 2015, 46, 68-82. [CrossRef]

11. Tang, X.; Wang, G. Design and analysis of e-commerce and modern logistics for regional economic integration in wireless networks. EURASIP J. Wirel. Commun. Netw. 2020, 2020, 208. [CrossRef]

12. Mentzer, J.T.; DeWitt, W.; Keebler, J.S.; Min, S.; Nix, N.W.; Smith, C.D.; Zacharia, Z.G. Defining supply chain management. J. Bus. Logist. 2011, 22, 1-25. [CrossRef]

13. Chopra, S.; Meindl, P. Supply Chain Management: Strategy, Planning, and Operation, 6th ed.; Pearson: New York, NY, USA, 2014.

14. Christopher, M. Logistics \& Supply Chain Management: Logistics \& Supply Chain Management, 5th ed.; FT Press: Upper Saddle River, NJ, USA, 2016.

15. Ricker, F.; Kalakota, R. Order fulfillment: The hidden key to e-commerce success. Supply Chain Manag. Rev. 1999, 11, 60-70.

16. Lambert, D.M.; Cooper, M.C. Issues in supply chain management. Ind. Mark. Manag. 2000, 29, 65-83. [CrossRef]

17. Rashid, K.; Aslam, M.M.H. Business excellence through total supply chain quality management. Asian J. Qual. 2012, 13, 309-324. [CrossRef]

18. Forno, A.J.D.; Pereira, F.A.; Forcellini, F.A.; Kipper, L.M. Value stream mapping: A study about the problems and challenges found in the literature from the past 15 years about application of Lean tools. Int. J. Adv. Manuf. Syst. 2014, 72, 779-790. [CrossRef] 
19. Krafcik, J.F. Triumph of the Lean Production System. MIT Sloan Manag. Rev. 1988, 30, 41-52.

20. Womack, J.P.; Jones, D.T.; Roos, D. The Machine That Changed the World; Rawson Associate: New York, NY, USA, 1990.

21. Womack, J.P.; Jones, D.T. Lean Thinking: Banish Waste and Create Wealth in your Corporation, 2nd ed.; Free Press: New York, NY, USA, 2003

22. Alukal, G. Lean kaizen in the 21st century. Qual. Prog. 2007, 40, 69-70.

23. Shah, R.; Ward, P.T. Defining and developing measures of lean production. J. Oper. Manag. 2007, 25, 785-805. [CrossRef]

24. Shararah, M.A. A value stream map in motion. Ind. Engi. 2013, 45, 46-50.

25. Martin, K.; Osterling, M. Value Stream Mapping: How to Visualize Work and Align Leadership for Organizational Transformation, 1st ed.; McGraw-Hill Education: New York, NY, USA, 2013.

26. Council for Six Sigma Certification; Setter, C.J. Six Sigma: A Complete Step-by-Step Guide: A Complete Training E Reference Guide for White Belts, Yellow Belts, Green Belts, and Black Belts; The Council for Six Sigma Certification: Buffalo, NY, USA, 2018.

27. Dos Santos, V.F.; Sabino, L.R.; Morais, G.M.; Gonçalves, C.A. E-commerce: A short history follow-up on possible trends. Int. J. Bus. 2017, 8, 130-138. [CrossRef]

28. Pant, S.; Sethi, R.; Bhandari, M. Making sense of the e-supply chain landscape: An implementation framework. J. Inf. Manag. 2003, 23, 201-221. [CrossRef]

29. Sherer, S.A. From supply-chain management to value network advocacy: Implications for e-supply chains. J. Supply Chain Manag. 2005, 10, 77-83. [CrossRef]

30. Chiang, W.K.; Monahan, G.E. Managing inventories in a two-echelon dual-channel supply chain. Eur. J. Oper. Res. 2005, 162, 325-341. [CrossRef]

31. Boone, T.; Ganeshan, R. Exploratory analysis of free shipping policies of online retailers. Int. J. Prod. Econ. 2013, 143, 627-632. [CrossRef]

32. Shao, X.F. Free or calculated shipping: Impact of delivery cost on supply chains moving to online retailing. Int. J. Prod. Econ. 2017, 191, 267-277. [CrossRef]

33. Piera, C.; Roberto, C.; Giuseppe, C.; Teresa, M. E-procurement and e-supply chain: Features and development of e-collaboration IERI Procedia 2014, 6, 8-14. [CrossRef]

34. Li, J.; Ghadge, A.; Tiwari, M.K. Impact of replenishment strategies on supply chain performance under e-shopping scenario. Comput. Ind. Eng. 2016, 102, 78-87. [CrossRef]

35. Xu, S.X.; Cheng, M.; Huang, G.Q. Efficient intermodal transportation auctions for b2b e-commerce logistics with transaction costs Transport. Res. B-Meth. 2015, 80, 322-337. [CrossRef]

36. Wang, W.; Li, G.; Cheng, T.C.E. Channel Selection in a Supply Chain with a Multi-Channel Retailer: The Role of Channel Operating Costs. Int. J. Prod. Econ. 2016, 173, 54-65. [CrossRef]

37. Zhang, J.; Wang, X.; Huang, K. Integrated on-line scheduling of order batching and delivery under b2c ecommerce. Comput. Ind. Eng. 2016, 94, 280-289. [CrossRef]

38. Zhao, J.; Hou, X.; Guo, Y.; Wei, J. Pricing policies for complementary products in a dual-channel supply chain. Appl. Math. Model. 2017, 49, 437-451. [CrossRef]

39. Byukusenge, E.; Munene, J.C. Knowledge management and business performance: Does innovation matter? Cogent Bus. Manag. 2017, 4, 1368434. [CrossRef]

40. Lestari, S.D.; Putra, A.H.P.K.; Muhdaliha, E. E-commerce performance based on knowledge management and organizational innovativeness. Distr. Sci. Res. 2020, 18, 49-58. [CrossRef]

41. Wang, Y.; Yu, Z.; Shen, L. Study on the decision-making and coordination of an e-commerce supply chain with manufacturer fairness concerns. Int. J. Prod. Res. 2019, 57, 2788-2808. [CrossRef]

42. Fedushko, S.; Shevchuk, L.; Poritska, A.; Kravets, R.; Tymovchak-Maksymets, O. E-Commerce and E-Health Strategies and Implementation Activities in the United Kingdom: Review Study. In Proceedings of the CEUR Workshop Proceedings. Vol-2647: Proceedings of the International Conference on Rural and Elderly Health Informatics (IREHI 2019), Dakar, Senegal, 4-6 December 2019. [CrossRef]

43. Syerov, Y.; Somych, N.; Ortynskyy, V.; Zakharchenko, A.; Lozynska, I. E-banking: Commerce and Legal Aspects. In Proceedings of the CEUR Workshop Proceedings. Vol-2824: Proceedings of the Symposium on Information Technologies \& Applied Sciences (IT\&AS 2021), Bratislava, Slovak Republic, 5 March 2021.

44. Kumar, S.; Lim, W.M.; Pandey, N.; Westland, J.C. 20 years of Electronic Commerce Research. Electron. Commer. Res. 2021, 21, 1-40. [CrossRef]

45. Rother, M.; Shook, J. Learning to See: Value Stream Mapping to Add Value and Eliminate Muda, 1st ed.; Lean Enterprise Institute: Boston, MA, USA, 1999

46. Singh, B.; Garg, S.K.; Sharma, S.K. Value stream mapping: Literature review and implications for Indian industry. Int. J. Adv. Manuf. Syst. 2011, 53, 799-809. [CrossRef]

47. Klimecka-Tatar, D. Analysis and improvement of business processes management-based on value stream mapping (vsm) in manufacturing companies. Pol. J. Manag. Stud. 2021, 23, 213. [CrossRef]

48. Shou, W.; Wang, J.; Wu, P.; Wang, X.; Chong, H. A cross-sector review on the use of value stream mapping. Int. J. Prod. Res. 2017, 55, 3906-3928. [CrossRef]

49. Tyagi, S.; Choudhary, A.; Cai, X.; Yang, K. Value stream mapping to reduce the lead-time of a product development process. Int. J. Prod. Econ. 2015, 160, 202-212. [CrossRef] 
50. Rosenbaum, S.; Toledo, M.; González, V. Improving environmental and production performance in construction projects using value-stream mapping: Case study. J. Constr. Eng. Manag. 2013, 140, 04013045. [CrossRef]

51. Muñoz-Villamizar, A.; Santos, J.; Garcia-Sabater, J.J.; Lleo, A.; Grau, P. Green value stream mapping approach to improving productivity and environmental performance. Int. J. Product. Perform. Manag. 2019, 68, 608-625. [CrossRef]

52. Schoeman, Y.; Oberholster, P.; Somerset, V. Value stream mapping as a supporting management tool to identify the flow of industrial waste: A case study. Sustainability 2021, 13, 91. [CrossRef]

53. Santos, A.C.S.G.D.; Reis, A.D.C.; Souza, C.G.; Santos, C.; Ferreria, I.L.; Figueiredo, L.A. The first evidence about conceptual vs analytical lean healthcare research studies. J. Health Organ. Manag. 2020, 34, 789-806. [CrossRef]

54. Marin-Garcia, J.A.; Vidal-Carreras, P.I.; Garcia-Sabater, J.J. The role of value stream mapping in healthcare services: A scoping review. Int. J. Environ. Res. Public Health 2021, 18, 951. [CrossRef]

55. Barber, C.S.; Tietje, B.C. A Research Agenda for Value Stream Mapping the Sales Process. J. Pers. Sell. Sales Manag. 2008, 28, 155-165. [CrossRef]

56. The Innovation Tools Handbook, Volume 1: Organizational and Operational Tools, Methods, and Techniques That Every Innovator Must Know; CRC Press: London, UK, 2016.

57. Serrat, O. Knowledge Solutions: Tools, Methods, and Approaches to Drive, 1st ed.; Springer Nature: Singapore, 2017.

58. Card, A.J. The problem with '5 whys'. BMJ Qual. Saf. 2017, 26, 671-677. [CrossRef] [PubMed]

59. Murugaiah, U.; Benjamin, J.; Marathamuthu, M.S.; Muthaiyah, S. Scrap loss reduction using the 5-whys analysis. Int. J. Qual. Reliab. 2010, 27, 527-540. [CrossRef]

60. Ding, S.H.; Muhammad, N.A.; Zulkurnaini, N.H.; Khaider, A.N.; Kamaruddin, S. Production system improvement by integration of fmea with 5-whys analysis. Adv. Mat. Res. 2013, 748, 1203-1207. [CrossRef]

61. Benjamin, S.J.; Marathamuthu, M.S.; Murugaiah, U. The use of 5-WHYs technique to eliminate OEE's speed loss in a manufacturing firm. J. Qual. Maint. Eng. 2015, 21, 419-435. [CrossRef]

62. Braglia, M.; Frosolini, M.; Gallo, M. SMED enhanced with 5-Whys analysis to improve set-up reduction programs: The SWAN approach. Int. J. Adv. Manuf. Techno. 2017, 90, 1845-1855. [CrossRef]

63. George, A.; Ranjha, S.; Kulkarni, A. Enhanced problem solving through redefined 8D step completion criteria. Qual. Eng. 2021, 33, 695-711. [CrossRef]

64. Zhu, F.; Liu, Q. Competing with complementors: An empirical look at Amazon.com. Strateg. Manag. J. 2018, $39,2618-2642$. [CrossRef]

65. Culpepper, P.D.; Thelen, K. Are we all Amazon primed? consumers and the politics of platform Power. Comp. Political Stud. 2020, 53, 288-318. [CrossRef]

66. Amazon. Available online: https://www.aboutamazon.com/impact/empowerment/small-businesses (accessed on 28 November 2021).

67. Yin, R.K. Case Study Research and Applications: Design and Methods, 6th ed.; SAGE Publications: Los Angeles, CA, USA, 2017.

68. Gerring, J. What Is a Case Study and What Is It Good for? Am. Political Sci. Rev. 2004, 98, 341-354. [CrossRef]

69. Suarez-Barraza, M.F.; Miguel-Davila, J.-Á.; Vasquez-García, C.F. Supply chain value stream mapping: A new tool of operation management. Int. J. Qual. Reliab. Manag. 2016, 33, 518-534. [CrossRef]

70. Reid, H. FBA vs. 3PL-Which Is the Best Amazon Fulfillment Option for You? 2020. Available online: https://dclcorp.com/blog/ amazon-fulfillment/amazon-fba-vs-3pl (accessed on 1 April 2021).

71. Fulfillment by Amazon (FBA) I How It Works. 2021. Available online: https://sell.amazon.com/fulfillment-by-amazon.html?ref_ =asus_soa_rd\& (accessed on 1 April 2021).

72. Connolly, B. Top Fulfillment Alternatives to Amazon FBA for 2021. 2021. Available online: https://www.junglescout.com/blog/ amazon-fulfillment-alternatives (accessed on 1 April 2021).

73. Ishikawa, A.; Amagasa, M.; Shiga, T.; Tomizawa, G.; Tatsuta, R.; Mieno, H. The max-min Delphi method and fuzzy Delphi method via fuzzy integration. Fuzzy Sets Syst. 1993, 55, 241-253. [CrossRef]

74. Liu, H.T.; Wang, W.K. An integrated fuzzy approach for provider evaluation and selection in third-party logistics. Expert Syst. Appl. 2009, 36, 4387-4398. [CrossRef]

75. Amazon Seller Central. 2021. Available online: https://sellercentral.amazon.com/ (accessed on 1 April 2021).

76. Exchange Rates-X-Rates. 2021. Available online: https://www.X-rates.com/ (accessed on 22 April 2021).

77. Neboha, E. E-commerce as a form of economic relationships of entrepreneurship subjects in the network economy. Econ. Ecol. Socium 2018, 2, 43-51. [CrossRef] 